\title{
Direct EPR Detection of Nitric Oxide in Mice Infected with the Pathogenic Mycobacterium Mycobacterium tuberculosis
}

\author{
Anatoly F. Vanin • Raisa P. Selitskaya • \\ Vladimir A. Serezhenkov • Galina N. Mozhokina
}

Received: 24 August 2009/Published online: 3 December 2009

(C) The Author(s) 2009. This article is published with open access at Springerlink.com

\begin{abstract}
It has been shown that treatment of mice preinfected with Mycobacterium tuberculosis with spin NO traps (iron complexes with diethyldithiocarbamate) enables detection of large amounts of NO in internal organs 2 and 4 weeks after infection (up to $55-57 \mu \mathrm{mol} / \mathrm{kg}$ of wet lung tissue accumulated with spin NO traps during $30 \mathrm{~min}$ ). The animals were infected with the drug-sensitive laboratory strain H37Rv and a clinical isolate nonrespondent to antituberculous drugs (the multidrugresistant strain of $M$. tuberculosis) obtained from a patient with an active form of tuberculosis. Two weeks after infection with the multidrug-resistant strain, the NO level in the lungs, spleen, liver and kidney increased sharply concurrently with slight lesions of lung tissue. A reverse correlation, i.e., low level of NO in the lungs and other internal organs and extensive injury of lung tissue, was established for H37Rv-infected mice. Four weeks after infection, NO production in the lungs increased dramatically for both $M$. tuberculosis strains resulting in 80-84\% damage of lung tissue. The lesion is suggested to be due to the development of defense mechanisms in $M$. tuberculosis counteracting NO effects.
\end{abstract}

\section{Introduction}

It was found that a combination of nitric oxide (NO) with active oxygen species affords effective protection of animals and men against pathogenic effects of mycobacteria, including the tuberculous pathogen Mycobacterium tuberculosis (Mtb) [1-16]. Localization of this pathogen in the lungs and other internal organs is

A. F. Vanin $(\bowtie) \cdot$ V. A. Serezhenkov

N.N. Semenov Institute of Chemical Physics, Russian Academy of Sciences, Moscow, Russia e-mail: vanin@polymer.chph.ras.ru

R. P. Selitskaya · G. N. Mozhokina

Research Institute for Phthisiopulmonology, I.M. Sechenov Moscow Medical Academy,

Moscow, Russia 
accompanied by infiltration of immunocompetent cells stimulated as a result of immune reaction with the pathogenic microorganism. This process initiates the synthesis of inducible NO synthase (NOS2), producing NO from L-arginine in immunecompetent cells (macrophages, neutrophils, etc.) [2-8, 11-14, 16]. The cytotoxic activity of NO produced by these cells triggers the formation of a protective system in $M t b$ able to resist the NO attack. The proteins constituting the system induce NO chemical modification. In addition, Mtb inhibits NOS2 expression in immunocompetent cells or eliminates the enzyme from the sites of intracellular mycobacterial residence, such as phagocytes [3, 12, 15, 17-28].

Therefore, quantitative assessment of NO levels in target tissues of $M t b$-infected animals acquires special importance because it sheds additional light on mechanisms of interaction between immune cells and $M t b$. Moreover, this problem has never been studied before. In the present investigation, this goal was achieved by application of the spin NO trap method, which was developed for the first time by our research group and employed hydrophobic iron complexes with diethyldithiocarbamate (DETC) as NO traps [29, 30]. Binding of NO to these complexes yields electron paramagnetic resonance (EPR)-active mononitrosyl iron complexes with DETC (MNIC-DETC) localized in hydrophobic compartments of the cell. Such type of MNIC-DETC localization justifies ex vivo approach for the estimation of NO levels in the organs isolated from animal organism. The intensity of EPR signals elicited by MNIC-DETC is commensurate with their concentration and, as a consequence, with tissue levels of NO. The experiments were carried out on mice infected with two Mtb strains, viz., sensitive and resistant to currently known antituberculous drugs. Measurements of NO levels in tissues were performed 2 or 4 weeks after infection. The degree of lung tissue injury was estimated in parallel experiments using a histological method.

\section{Materials and Methods}

\subsection{Materials}

The following reagents were used: DETC (Sigma, USA), $N$-methyl-D-glucamine dithiocarbamate (MGD, synthesized as described in Ref. [31]). Ferrous sulfate was from Fluka (Switzerland). Gaseous NO was obtained by a reaction of $\mathrm{FeSO}_{4}$ with $\mathrm{NaNO}_{2}$ in $0.1 \mathrm{M} \mathrm{HCl}$. The escaping $\mathrm{NO}$ gas was additionally purified by lowtemperature sublimation in an evacuated glass system. The MNIC-MGD solutions of known concentrations were synthesized as described in Ref. [31].

\subsection{Animal Studies}

The experiments were carried out on 60 inbred male albino mice weighing 18-20 g. The animals were infected with two different strains of $M t b\left(5 \times 10^{4}\right.$ cells per animal, intravenously), viz., a drug-sensitive laboratory strain (H37Rv) and an anonymous clinical isolate nonrespondent to the majority of existing antituberculous drugs (guaniazide, streptomycin, ridamycin). The latter represented a 
multidrug-resistant $M t b$ strain obtained from a patient with active tuberculosis at Research Institute for Phthisiopulmonology, I.M. Sechenov Moscow Medical Academy, Moscow. Two and four weeks after infection, the animals were sacrificed by cervical dislocation; lung tissue was extracted and analyzed histologically. For histological analysis, small tissue fragments were fixed in Bowen fluid; after fixation and sampling, the test material was fixed in paraffin. Serial slides were prepared from bulk paraffin using hematoxylin and eosin as dyes. The volumetric density (vol \%) of tuberculous pneumonia foci in histological slides was calculated by the points rating method based on the use of the Avtandilov grid test $(100 \times$ magnification) [32].

In experiments designed to measure the NO content in internal organs (lungs, spleen, liver and kidney) $30 \mathrm{~min}$ before killing, infected animals were additionally treated with DETC $(500 \mathrm{mg} / \mathrm{kg}$, intraperitoneally) and an iron-citrate complex $\left(37.5 \mathrm{mg} / \mathrm{kg} \mathrm{FeSO} \cdot 7 \mathrm{H}_{2} \mathrm{O}+187.5 \mathrm{mg} / \mathrm{kg}\right.$ sodium citrate, intramuscularly into the leg). On entering target organs, iron and DETC initiated the formation of NO spin traps and lipophilic iron-DETC complexes localized in hydrophobic cell compartments. Their binding to NO yielded paramagnetic MNIC-DETC detectable by the EPR method [29, 30, 33]. After extraction, internal organs were frozen in liquid nitrogen for storage and measurement of EPR spectra. This approach enabled 30-min measurement of NO generation rates in target organs and NO accumulation in spin traps. In parallel experiments, the rates of formation of paramagnetic nitrosyl hemoglobin complexes were determined in animal blood using the EPR method.

Previously, it was found that high values of rate constants for NO binding to iron-DETC complexes and high concentration of these NO traps in animal organs are prerequisite to high rates of NO binding by these traps [33]. The latter markedly exceeded the rates of NO trapping by endogenous compounds, e.g., superoxide or hemoglobin. This suggests that the method for NO detection adequately reflects NO production in living organisms without artifact effects of potential NO scavengers.

\subsection{EPR Measurements}

EPR spectra were measured in frozen animal organs (lungs, liver, spleen and kidney) and blood at $77 \mathrm{~K}$ on a microwave spectrometer ESC-106 (Bruker, Germany; microwave power, $5 \mathrm{~mW}$; magnetic field modulation amplitude, $0.5 \mathrm{mT}$ ). The concentration of paramagnetic centers of experimental samples was determined from integral intensities of EPR signals by comparing double integrals of EPR signals to those of experimental and standard samples. Frozen solutions of MNICMGD of known concentrations were used as standards.

\subsection{Statistic Treatment of Experimental Data}

The data were presented as mean \pm standard error of the mean (SEM) of five individual observations from different mice $(p<0.01 \mathrm{vs}$. corresponding differences among the groups of rats). 


\section{Results}

The EPR signals of MNIC-DETC recorded in the lungs, spleen, liver and kidney tissues of mice 2 weeks after their infection with the drug-resistant or drug-sensitive strain of $M t b$ are shown in Fig. 1. Regarding their shape and spectroscopic characteristics ( $g=2.035$, presence of a triplet hyperfine structure determined by interaction of the unpaired electron with the nitrogen nucleus of NO, etc.), these signals are identical with those reported previously for MNIC-DETC [29, 30, 3341]. The concentrations of NO incorporated into MNIC-DETC in lung, spleen, liver and kidney tissues during 30 min estimated from the corresponding EPR signals are listed in Table 1. For comparison sake, Table 1 provides the NO content in respective organs of control (noninfected) animals. From Table 1 and Fig. 1, it follows that infection of mice with the drug-resistant $M t b$ strain caused a dramatic increase in the NO level in all internal organs as early as 2 weeks after infection. The pathological changes were especially well-pronounced in the spleen and the lungs, most probably due to specific localization of $M t b$ in these organs.

According to previously published data $[2,8,11-14,16]$, NO synthesis in tissues of $M t b$-infected mice was localized in immunocompetent cells (macrophages, neutrophils) and occurred via an L-arginine-dependent pathway. This hypothesis was verified in experiments in which mice infected with the multidrug-resistant strain of Mtb were treated with the nonspecific NOS inhibitor nitro-L-arginine at the end of the second postinfection week. The inhibitor was administered to animals in the dose of $50 \mathrm{mg} / \mathrm{animal} 30 \mathrm{~min}$ before the spin trap injection. As a result, the intensity of the EPR signal of MNIC-DETC in mouse lungs diminished by $65-67 \%$.

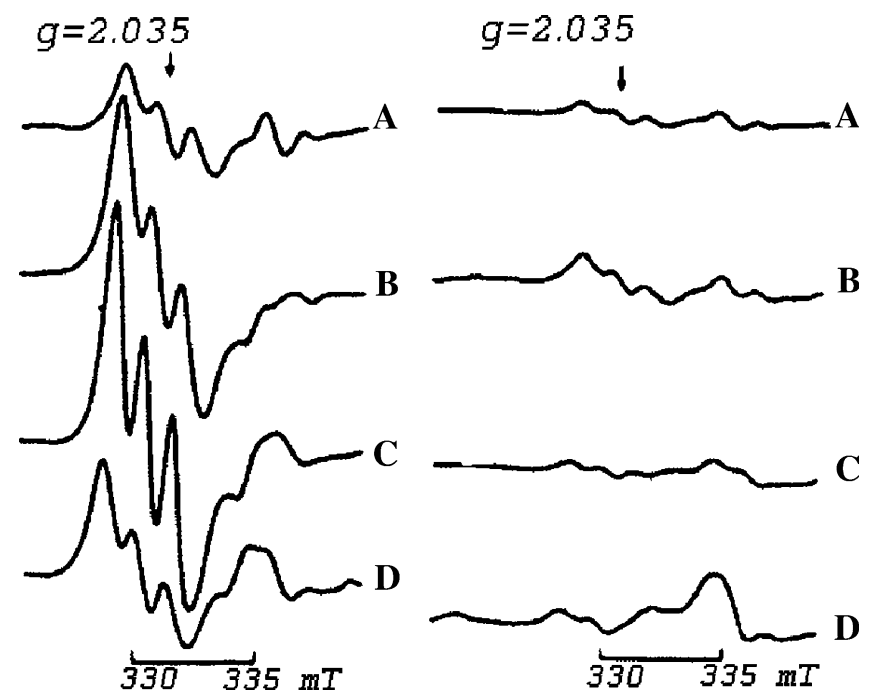

Fig. 1 EPR spectra of lung $(A)$, spleen $(B)$, liver $(C)$ and kidney $(D)$ MNIC-DETC measured 2 weeks after infection of mice with the multidrug-resistant strain (left panel) or the drug-sensitive strain (right panel). The amplifications of the EPR spectrometer were $10^{4}(A) ; 10^{4}(B) ; 10^{5}(C)$; or $2 \times 10^{5}(D)$. The spectra were recorded at $77 \mathrm{~K}$, microwave power of $5 \mathrm{~mW}$, and modulation amplitude of $0.5 \mathrm{mT}$ 
Table 1 NO accumulation (30 min) in internal organs of mice infected with $M t b$ ( $\mu \mathrm{mol} / \mathrm{kg}$ of tissue)

\begin{tabular}{|c|c|c|c|c|c|}
\hline \multirow[t]{2}{*}{ Tissue } & \multirow[t]{2}{*}{$\begin{array}{l}\text { Control }(\text { mean } \pm \text { SEM), } \\
\mu \mathrm{mol} / \mathrm{kg}\end{array}$} & \multicolumn{2}{|c|}{$\begin{array}{l}\text { Multidrug-resistant strain } \\
(\text { mean } \pm \mathrm{SEM}), \mu \mathrm{mol} / \mathrm{kg}\end{array}$} & \multicolumn{2}{|c|}{$\begin{array}{l}\text { Drug-sensitive H37Rv strain } \\
(\text { mean } \pm \mathrm{SEM}), \mu \mathrm{mol} / \mathrm{kg}\end{array}$} \\
\hline & & Week 2 & Week 4 & Week 2 & Week 4 \\
\hline Lungs & $0.5 \pm 0.4$ & $31.6 \pm 9.7$ & $54.6 \pm 21.5$ & $4.6 \pm 1.8$ & $57.3 \pm 24.2$ \\
\hline Spleen & $1.0 \pm 0.5$ & $93.8 \pm 26.9$ & $51.4 \pm 16.4$ & $13.2 \pm 4.6$ & $37.2 \pm 12.8$ \\
\hline Liver & $2.0 \pm 0.5$ & $17.6 \pm 4.8$ & $6.0 \pm 2.3$ & $0.7 \pm 0.3$ & $5.3 \pm 2.4$ \\
\hline Kidney & $1.1 \pm 0.4$ & $5.9 \pm 2.7$ & $3.6 \pm 1.4$ & $0.2 \pm 0.1$ & $1.2 \pm 0.5$ \\
\hline
\end{tabular}

Histological analysis of lung tissues carried out at the end of the second week after infection of mice with the multidrug-resistant strain of $M t b$ revealed signs of microfocal interstitial pneumonia with major focal infiltration of immunocompetent cells into alveolar septae (Fig. 2, left panel). Judging from EPR data (Fig. 1; Table 1), this gave rise to enhanced production of NO in the lungs to an extent sufficient to suppress $M t b$ proliferation. Histological data suggest that the volumetric density of tuberculous lesions of lung tissue at the end of the second week after infection of mice with $M t b$ dropped down to $7.1 \pm 1.1$ vol\% (Table 2).

In mice infected with the drug-sensitive strain of $M t b$, notable increases in NO levels were found only in the spleen and lungs 2 weeks after infection. Noteworthy, these increases were substantially lower than in mice infected with the multidrugresistant strain of $M t b$ (Table 1). The difference could be due to less intensive infiltration of NO-generating immunocompetent cells into the aforesaid organs in mice infected with the drug-sensitive strain of $M t b$. However, histological analysis of lung tissues revealed signs of interstitial pneumonia and pronounced diffuse-focal infiltration of immunocompetent cells into alveolar walls (Fig. 2, right panel). The volumetric density of the pathological foci was $54.3 \pm 9.0$ vol\% (Table 2). This
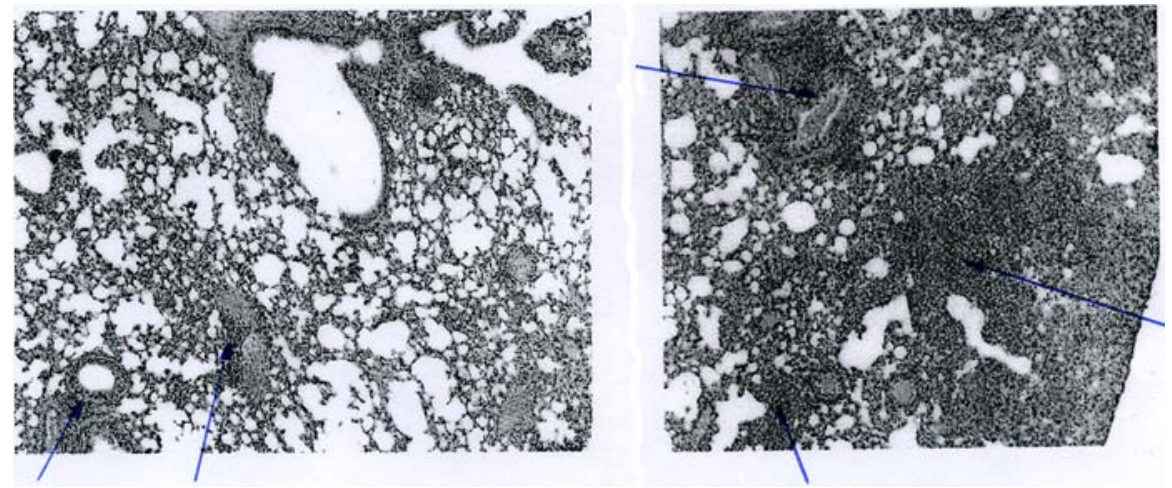

Fig. 2 Mouse lungs examined 2 weeks after infection with the drug-resistant (left panel) and drugsensitive (right panel) strains of $M t b$. Left panel the arrows indicate typical small interstitial pneumonia foci with slight focal infiltration of interalveolar septae by immunocompetent cells. Right panel interstitial pneumonia manifested as strong diffuse-focal infiltration of interalveolar septae by immunocompetent cells (indicated by arrows) 
Table 2 Degree of lung tissue lesion in mice infected with $M t b$

\begin{tabular}{|c|c|c|c|c|}
\hline \multirow[t]{2}{*}{ Tissue } & \multicolumn{2}{|c|}{$\begin{array}{l}\text { Multidrug-resistant (wild) } \\
\text { strain (mean } \pm \text { SEM), \% }\end{array}$} & \multicolumn{2}{|c|}{$\begin{array}{l}\text { Drug-sensitive (laboratory) } \\
\text { strain }(\mathrm{H} 37 \mathrm{Rv})(\text { mean } \pm \mathrm{SEM}), \%\end{array}$} \\
\hline & Week 2 & Week 4 & Week 2 & Week 4 \\
\hline Lung & $7.0 \pm 1.1$ & $77.9 \pm 8.3$ & $54.3 \pm 9.0$ & $84.3 \pm 10.6$ \\
\hline
\end{tabular}

finding allowed us to suggest that infiltration of immune cells into lung tissues of mice infected with the drug-sensitive strain of $M t b$ did not prevent proliferation of mycobacteria in lung tissues, which correlated with the low level of NO generation in these cells. The reason is still unclear; it is not excluded that this Mtb strain suppresses NO production in immunocompetent cells, at least within the first two postinfection weeks. According to literature data, such capability is specific only for certain $M t b$ strains $[3,12,15,17,18]$.

The sharp increase in the NO level in internal organs of mice infected with the drug-sensitive strain of $M t b$ in the subsequent 2 weeks (Table 1) was especially apparent in the lungs and spleen tissues during the first 2 weeks. In mice infected with the multidrug-resistant strain of $M t b$, NO elevation was observed on week 4 only in the lungs, being decreased in other organs (see Table 1). According to histological data (not shown), the rate of proliferation of $M t b$ and the degree of lung tissue lesion increased sharply in mice infected with both $M t b$ strains (Table 2).

The EPR spectra of blood of mice infected with the multidrug-resistant strain of $M t b$ displayed the presence, in addition to MNIC-DETC lines, of broader EPR signals corresponding to nitrosyl hemoglolbin complexes ( $\mathrm{Hb}-\mathrm{NO})$ at $g$-factor values of 2.07 and 1.98 (Fig. 3A and B). For comparison sake, Fig. 3D contained a more intense EPR signal for $\mathrm{Hb}-\mathrm{NO}$ recorded in blood sera of mice treated with gaseous NO. The concentration of $\mathrm{Hb}-\mathrm{NO}$ complexes in the blood of mice infected with the multidrug-resistant strain of $M t b$ increased in a time-dependent manner, being equal to $0.9 \pm 0.4 \mu \mathrm{mol} / \mathrm{l} 2$ weeks after infection and to $2.3 \pm 0.9 \mu \mathrm{mol} / \mathrm{l}$ 4 weeks after infection. In addition to $\mathrm{Hb}-\mathrm{NO}$ and MNIC-DETC signals, the EPR spectrum displayed in Fig. 3a has four components (designated as a, b, c and d, respectively) corresponding to the hyperfine structure of the EPR signal of $\mathrm{Cu}^{2+}-$ DETC complexes [29]. The latter was also present in the EPR spectrum of control animals treated with MNIC-DETC (Fig. 3C). No EPR signals of $\mathrm{Hb}-\mathrm{NO}$ or MNIC-DETC were found in blood of animals infected with the drug-sensitive strain of $M t b$.

\section{Discussion}

The data obtained suggest that the use of iron complexes with DETC as spin NO traps allows 30-min monitoring of NO formation in animals infected with Mtb. In mice infected with the multidrug-resistant strain of $M t b$, high NO concentrations were noted even on the second postinfection week and were accompanied by inhibition of proliferation of the tuberculous pathogen in lung tissue as can be 


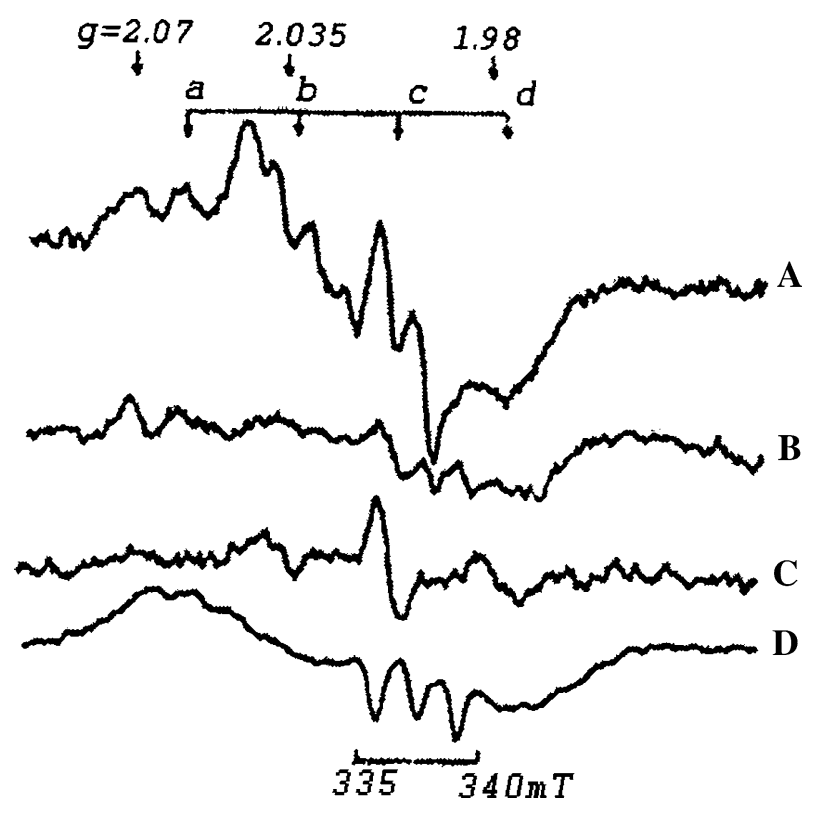

Fig. 3 EPR spectra of mouse blood measured on week $4(A)$ or week $2(B)$ after infection of animals with the multidrug-resistant strain and added DETCciron complexes. $C$ EPR spectrum of blood from noninfected mice treated with DETC-iron complexes. $D$ EPR spectrum of $\mathrm{Hb}-\mathrm{NO}$ isolated from mouse blood treated with gaseous nitric oxide used at concentration corresponding to $1.5 \mu \mathrm{mol}$ of $\mathrm{Hb}-\mathrm{NO}$ per 11 of blood. $a-d$ Components of the hyperfine structure of the $\mathrm{Cu}^{2+}-$ DETC EPR signal. Spectra were recorded at $77 \mathrm{~K}$, microwave power of $5 \mathrm{~mW}$, modulation amplitude of $0.5 \mathrm{mT}$ and $5 \times 10^{5}(A-C)$ or $1 \times 10^{5}(D)$ amplification of the EPR spectrometer

judged from low degree of lesion of this organ. In animals infected with the drugsensitive strain of $M t b$, NO elevation occurred more slowly and was manifested in severe lesions of lung tissue as early as 2 weeks after infection. This suggests that NO production by immunocompetent cells inhibits, at least on the initial steps of infection, the proliferation of the tuberculous pathogen. This finding is in good agreement with the previously reported data and reflects the cytotoxic and protective effects of NO against $M t b$ [1-16].

Noteworthy, on week 4 the beneficial therapeutic effect of enhanced NO synthesis was absent in both animal groups despite the high content of this cytotoxic agent (Table 1): the extent of lung lesion increased to 80-84\% (Table 2). Such a high degree of lung injury can be attributed to the ability of $M t b$ to trigger the synthesis of proteins able to modulate NO activity and to make NO nonhazardous for mycobacteria. According to literature data, the role of such proteins in $M t b$ is played by flavohemoglobin homologues $[12,18]$ or truncated $\mathrm{Hb}(\mathrm{HbN})[12,22$, 26]. The latter catalyzes oxygen-mediated oxidation of $\mathrm{NO}$ to nitrates, whereas flavohemoglobin additionally catalyzes $\mathrm{NO}$ reduction to $\mathrm{N}_{2} \mathrm{O}$ under anoxia.

Enhanced production of NO in animals infected with the multidrug-resistant strain was accompanied by the formation of circulating nitrosyl hemoglobin complexes. Interestingly, the concentration of the latter increased with time. No 
such complexes were found in the blood of animals infected with the drug-sensitive strain, even on week 4 after infection against the background of dramatically enhanced NO synthesis (Table 1). However, this finding needs further verification.

By week 4, NO synthesis in the liver, spleen and kidney of mice infected with the multidrug-resistant strain of $M t b$ was sharply decreased concomitantly with notably increased $\mathrm{Hb}-\mathrm{NO}$ content. Enhanced synthesis of NO was observed only in lung tissue (Table 1). It is not excluded that the low level of NO synthesis in other organs was due to depletion of intracellular pools of the NOS2 substrate L-arginine in immunocompetent cells. No such event took place in immune cells of mice infected with the drug-sensitive strain $M t b$, enhanced NO production in which was noted only on weak 4 after infection (Table 1).

It is noteworthy that high level of NO synthesis observed in lung tissue on week 4 after infection of mice with both $M t b$ strains amounted to $55-57 \mu \mathrm{mol} / \mathrm{kg}$ of wet tissue during the process of NO spin trapping $(30 \mathrm{~min})$. The value approximated the NO level established previously by the iron-dithiocarbamate method in liver tissues (100 $\mu \mathrm{mol} / \mathrm{kg}$ of wet tissue) of mice treated with a bacterial lipopolysaccharide (LPS). The latter is known to initiate inflammatory processes and enhanced NO synthesis in animal organisms [35, 42]. Interestingly, in lung tissues of LPS-treated animals the NO level did not exceed $10 \mu \mathrm{mol} / \mathrm{kg}$ of wet tissue.

This fact notwithstanding, the high level of the NO production in lung tissues of $M t b$-infected mice was too low to overcome the immune barrier of mycobacterial cells formed in response to NO attack. It was tempting to speculate that this protective barrier can be overcome at higher rates of NO accumulation in the infected lung. One of the approaches consists in treatment of infected animals with the NOS2 substrate L-arginine; the alternative approach consists in injection of exogenous NO donors. Numerous attempts to use NO-ates or $S$-nitrosothiols as NO donors were undertaken in previous studies [1, 9, 43-45]. However, the lack of strong evidence suggests that NO generation induced by these factors is short-term and insufficient for stimulating cytotoxic activity of NO. The NO thus generated is rapidly deactivated in a reaction with the superoxide, eventually resulting in fast (within several seconds) decomposition of the peroxynitrite formed. The role of an efficient long-acting NO donor can be played by low-molecular dinitrosyl iron complexes (DNIC). On entering the organism, these complexes are converted into protein-bound DNIC as a result of a transfer of $\mathrm{Fe}(\mathrm{NO})_{2}$ groups from low-molecular DNIC to thiol groups of proteins. Protein-bound DNIC are more stable than their low-molecular-weight analogs, which are prerequisite to long-term (up to $60 \mathrm{~min}$ and longer periods) release of NO into the intracellular space [46, 47].

Increased sensitivity of the multidrug-resistant $M t b$ strain to cytotoxic effect of NO (at least during the first 2 weeks after infection) and its high resistance to the main antituberculous drugs (guaniside, streptomycin, ridamycin) suggest that the effects of the latter on mycobacteria is not coupled with initiation of NO synthesis in immunocompetent cells. It is not excluded that NO produced by immunocompetent cells or efficient exogenous donors exerts a more potent protective antimycobacterial effect on both $M t b$ strains than the aforementioned drugs. Interestingly, the drugsensitive $M t b$ strain appeared to be resistant, at least within the first two postinfection weeks, to NO-producing immunocompetent cells. The results of present study 
strongly suggest that such an effect is due to the ability of this $M t b$ strain to inhibit NO production, as was established earlier for several $M t b$ strains [3, 12, 15, 17, 18]. However, this hypothesis demands further verification and experiment.

Acknowledgment This work was supported by the Russian Foundation for Basic Research (grant nr. 09-04-00868a).

Open Access This article is distributed under the terms of the Creative Commons Attribution Noncommercial License which permits any noncommercial use, distribution, and reproduction in any medium, provided the original author(s) and source are credited.

\section{References}

1. L. O’Brien, J. Carmichael, D.R. Lowrie, P.W. Andrew, Infect. Immun. 62, 5187-5190 (1994)

2. J. Han, K. Tanaka, D. Carroll, J. Flynn, B.R. Bloom, Infect. Immun. 63, 736-740 (1995)

3. T.R. Garbe, N.S. Hibler, V. Deretich, Mol. Med. 2, 134-142 (1996)

4. L.B. Adams, M.C. Dinauer, D.E. Morgenstern, J.L. Krahenbuhl, Tuber. Lung Dis. 78, 237-246 (1997)

5. J.D. MacMicking, R.J. North, R. LaCourse, J.S. Mudgett, S.K. Shan, C.F. Nathan, Proc. Natl. Acad. Sci. USA 94, 5243-5248 (1997)

6. M. Arias, M. Rojas, J. Zabaleta, J.I. Rodriguez, S.C. Paris, L.F. Barrera, L.F. Garcia, J. Infect. Dis. 178, 1552-1558 (1997)

7. O.J. Kwon, J. Korean Med. Sci. 12, 481-487 (1997)

8. C. Jaganath, J.K. Actor, R.L. Hunter, Nitric Oxide 2, 174-186 (1998)

9. R. Long, B. Light, J.A. Talbot, Antimicrob. Agents Chemother. 43, 403-405 (1999)

10. C. Sciorati, P. Rovere, M. Ferrarini, C. Paolucci, S. Heltai, R. Vaivani, E. Clementi, A.A. Manfredi, J. Immunol. 163, 1570-1576 (1999)

11. M. Bose, P. Farnia, S. Sharma, D. Chattapadhya, K. Saha, Int. J. Immunopathol. Pharmacol. 12, 69-79 (1999)

12. C. Nathan, M.U. Shiloh, Proc. Natl. Acad. Sci. USA 97, 8841-8848 (2000)

13. C.A. Scanga, V.P. Mohan, K. Tanaka, D. Alland, J.L. Flynn, J. Chan, Infect. Immun. 69, 7711-7717 (2001)

14. C. Li, A.Y. Xing, P.J. Wei, S.X. Gu, H.Y. Chen, H.F. Duan, X. Chen, L. Xie, Y. Ma, Chin. J. Tubercul. Respir. Dis. 26, 214-217 (2003)

15. K.H. Darwin, S. Ehrt, J.-C. Gutierrez-Ramos, N. Weich, C.F. Nathan, Science 302, 1963-1966 (2003)

16. K.Y. Rhee, H. Erdjument-Bromage, P. Tempst, C.F. Nathan, Proc. Natl. Acad. Sci. USA 102, 467-472 (2005)

17. B.G. Marshall, M.A. Chambers, A. Wangoo, R.S. Shaw, D.B. Young, Infect. Immun. 65, 1931-1935 (1997)

18. Y. Hu, P.D. Butcher, J.A. Mangan, M.-A. Rajandream, A.R.M. Coates, J. Bacteriol. 181, 3486-3493 (1999)

19. R. Bryk, P. Griffin, C. Nathan, Nature 407, 211-215 (2000)

20. M.I. Vascuil, D. Schnappinger, K.C. Visconi, M.I. Harrell, G.M. Dolganov, D.R. Sherman, G.R. Schoolnik, J. Exp. Med. 198, 705-713 (2003)

21. J. Pieters, H. Ploegh, Science 302, 1900-1902 (2003)

22. M. Milani, A. Pesce, H. Ouellet, M. Bolognesi, IUBMB Life 55, 623-627 (2003)

23. B.H. Miller, R.A. Fratti, J.F. Poshet, G.S. Timmins, S.S. Master, M. Burgos, M.A. Marletta, V. Deretic, Infect. Immun. 72, 2872-2878 (2004)

24. C.A. Scanga, A. Bafica, C.G. Feng, A.W. Cheever, S. Hieny, A. Sher, Infect. Immun. 72, 2400-2404 (2004)

25. S. Kurtz, K.P. McKinnon, M.S. Runge, J.P.-Y. Ting, M. Braunstein, Infect. Immun. 74, 6855-6864 (2006) 
26. A. Lama, S. Pawaria, K.L. Dikshit, FEBS Lett. 580, 4031-4041 (2006)

27. A. Singh, L. Guidry, K.V. Narasimhulu, D. Mai, J. Trombley, K.E. Redding, G.I. Giles, J.R. Lancaster, A.J.C. Steyn, Proc. Natl. Acad. Sci. USA 104, 11562-11567 (2007)

28. A. Davis, I. Vergne, S.S. Master, G.B. Kyei, J. Chua, V. Deretic, PloS Pathog. 3, 1887-1894 (2007)

29. A.F. Vanin, P.I. Mordvintcev, A.L. Kleschyov, Stud. Biophys. 102, 135-143 (1985)

30. L.N. Kubrina, W.S. Caldwell, P.I. Mordvintcev, I.V. Malenkova, A.F. Vanin, Biochim. Biophys. Acta 1099, 233-237 (1992)

31. L.A. Shinobu, S.G. Jones, M.M. Jones, Acta Pharmacol. Toxicol. 54, 189-194 (1984)

32. G.G. Avtandilov, Meditsinskaya Morphometriya (Meditsina Press, Moscow, 1990), pp. 65-77 (in Russian)

33. A.F. Vanin, A. Huisman, E. van Faassen, Methods Enzymol. 359, 27-42 (2002)

34. B.A. Goodman, J.B. Raynor, M.C.R. Simmons, J. Chem. Soc. (A) 17, 2572-2575 (1969)

35. V. Quaresima, H. Takehara, M. Ferrari, H. Utsumi, Biochim. Biophys. Res. Comm. 221, 729-734 (1996)

36. T. Tominaga, S. Sato, T. Ohnishi, S.T. Ohnishi, Brain Res. 614, 342-346 (1993)

37. A. Mülsch, R. Busse, P.I. Mordvintcev, A.F. Vanin, E.O. Nielsen, J. Scheel-Kruger, S.-P. Olesen, Neuro Rep. 5, 2325-2328 (1994)

38. D.C. Hooper, S.T. Ohnishi, R. Kean, Y. Numagami, B. Dietzschold, H. Koprowski, Proc. Natl. Acad. Sci. USA 92, 5312-5316 (1995)

39. T. Akaike, Y. Noguchi, S. Ijiri, K. Setoguchi, M. Suga, Y.M. Zheng, B. Dietzschold, H. Maeda, Proc. Natl. Acad. Sci. USA 93, 2448-2453 (1996)

40. Y.A. Henry, A. Guissani, B. Ducastel, Nitric Oxide Research from Chemistry to Biology: EPR Spectroscopy of Nitrosylated Compounds (Landes, RG, Austin, 1997)

41. T. Nagano, T. Yoshimura, Chem. Rev. 102, 1235-1269 (2002)

42. L.N. Kubrina, V.D. Mikoyan, P.I. Mordvintcev, A.F. Vanin, Biochim. Biophys. Acta 1176, 2450-2454 (1997)

43. A.Y. Coban, G. Bayramoglu, B. Ekinci, B. Durupinar, Mikrobiol. Bul. 37, 151-155 (2003)

44. V. Venketaraman, Y.K. Dayaram, M.T. Talaue, N.D. Connel, Infect. Immun. 73, 1886-1889 (2005)

45. T.R. Gabre, N.S. Hibler, V. Deretic, Infect. Immun. 67, 460-465 (1999)

46. A.F. Vanin, E. van Faassen, in Radicals for Life: The Various Forms of Nitric Oxide, ed. by E. van Faassen, A.F. Vanin (Elsevier, Amsterdam, 2007), pp. 19-73

47. V.L. Lakomkin, A.F. Vanin, A.A. Timoshin, V.I. Kapel`ko, E.I. Chazov, Nitric Oxide 16, 413-418 (2007) 